\title{
Eosinophilic Esophagitis
}

\author{
Esofagite Eosinofílica
}

Samuel COSTA $\rrbracket^{1}$, Margarida FERREIRA², Bruno GONÇALVES ${ }^{1}$, Raquel GONÇALVES ${ }^{1}$

Acta Med Port 2016 May;29(5):348-348 - http://dx.doi.org/10.20344/amp.6909

Keywords: Eosinophilic Esophagitis.

Palavras-chave: Esofagite Eosinofílica.

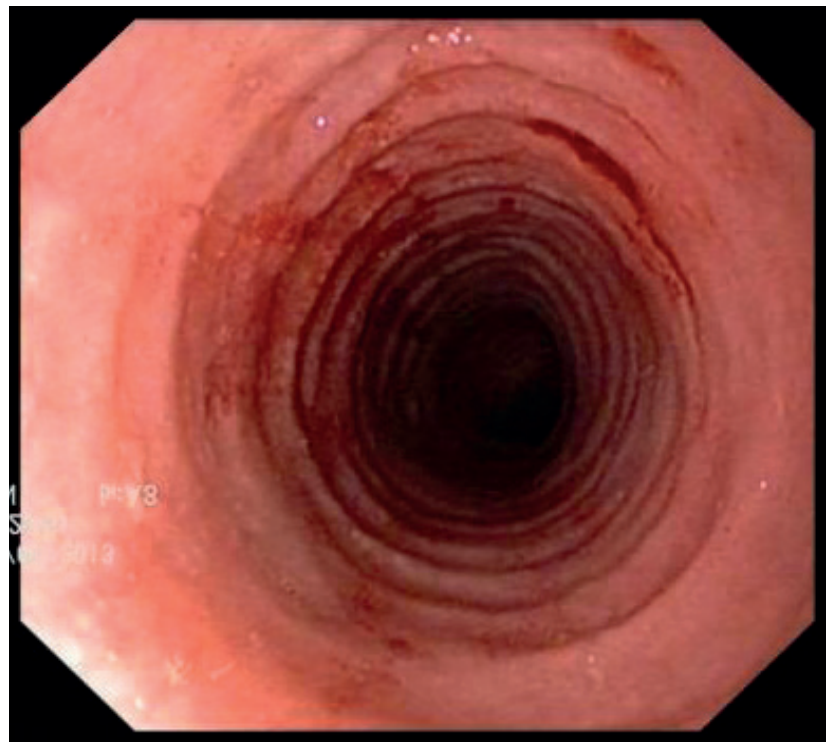

Figure 1 - EGD - concentric rings.

A young male (31 years) went to the Emergency by food impaction. He denied heartburn, thoracic pain or weight loss and had not atopic dermatitis, rhinitis/sinusitis, atopic asthma or food allergy.

The first episode of impaction occurred one year and half before; at that time the esophagogastroduodenoscopy (EGD) showed meat impaction in middle esophagus and narrow-caliber esophagus. He was medicated with proton pump inhibitor (PPI) and oriented to Gastroenterology consultation but did not come.

The second time the EGD revealed another characte-

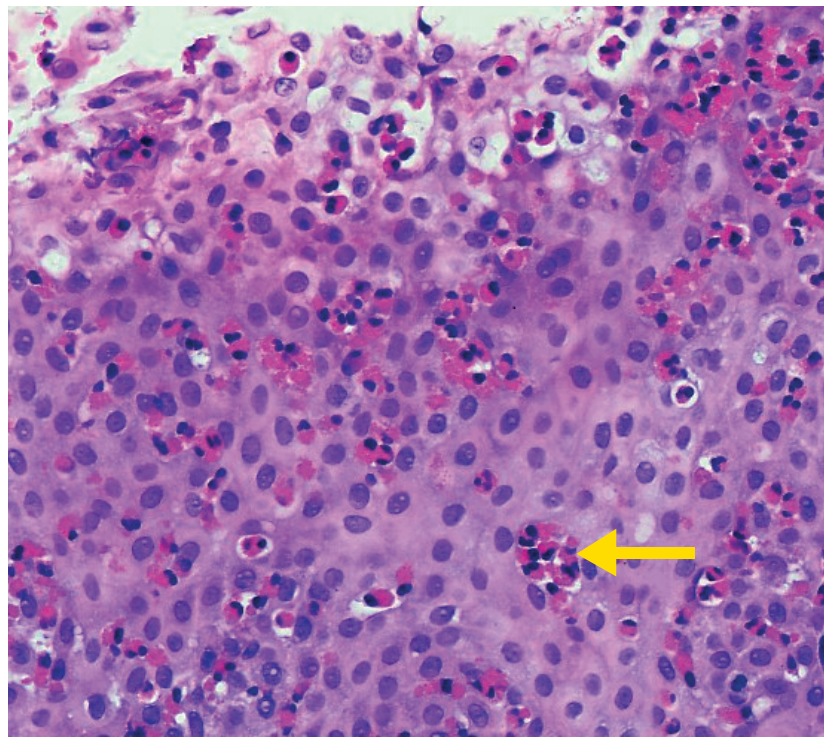

Figure 2 - Histology - eosinophilic infiltrate (> 20 eosinophils per high power field magnification-HE $400 \mathrm{X}$ ) and eosinophilic microabscesses (arrow).

ristic finding: esophagus with concentric rings (Fig. 1). Esophageal biopsies showed eosinophilic infiltrate (> 20 eosinophils per high power field magnification) and eosinophilic microabscesses (Fig. 2).

The endoscopic appearance, eosinophilic infiltrate, absence of response to PPI treatment and frank improvement after the introduction of topical corticosteroid (swallowed fluticasone) confirmed the diagnosis of eosinophilic esophagitis. ${ }^{1,2}$

We intend to show one of the most characteristic endoscopic aspect of the disease: esophageal rings.

\section{REFERENCES}

1. Couto M, Rodrigues S, Piedade S, Gaspar A, Almeida MM, Macedo M. Esofagite eosinofílica. Acta Med Port. 2011,24:949-60.

2. Dellon ES. Diagnosis and management of eosinophilic esophagitis. Clin Gastroenterol Hepatol. 2012;10:1066-78.

\footnotetext{
1. Gastroenterology Department. Hospital de Braga. Braga. Portugal.

2. Pathology Department. Hospital de Braga. Braga. Portugal.

$\bowtie$ Autor correspondente: Samuel Costa. samuelcosta@hotmail.com

Recebido: 12 de agosto de 2015 - Aceite: 26 de dezembro de 2015 | Copyright @ Ordem dos Médicos 2016
} 